\title{
Nemogućnost hibridizacije čovjeka i antropoidnih majmuna
}

\author{
Tonći Kokić*
}

\begin{abstract}
Sažetak
Ovaj rad iz perspektiva filozofije biologije i filozofske antropologije tvrdi načelnu nemogućnost hibridnoga potomstva čovjeka i genskih srodnika iz vrsta antropoidnih majmuna. Ta se tvrdnja izvodi iz suvremene znanstvene spoznaje o manjoj genskoj sličnosti čovjeka i majmuna nego se ranije mislilo (uz oslabljenu poziciju genetskoga redukcionizma) i supstancijalne razlike morfologija dviju vrsta. Hibrid tih dviju vrsta nije moguć logički ni ontološki jer bi morao spajati kontradiktorna morfološka obilježja.
\end{abstract}

Ključne riječi: filozofska antropologija, filozofija biologije, genetski redukcionizam, hibrid, morfologija

\section{Uvod}

O mogućnosti hibridizacije anatomski modernih ljudi, (pod)vrste (sapiens sapiens) iz roda Homo, i vrste obične čimpanze (troglodytes) iz roda Pan ili vrsta iz rodova Pongo i/ili Gorilla, nema znanstvenoga konsenzusa. Ljudi kroz tu dilemu traže odgovor i na pitanje: Kako smo nastali, tko smo i kakva je naša narav? Uspješna hibridizacija između tih vrsta vjerojatno bi, uz znanstvene, biološke i klasifikacijsko-sistematske, imala i snažne antropološko-etičke implikacije izmicanja ekskluzivnosti čovjeka i njegovoj regresiji u sferu čisto animalnoga.

Za raspravu o mogućnosti hibridizacije prije svega treba razlučiti značenje termina hibrid, tj. potomak od roditelja koji se razlikuju u barem jednom obilježju, od termina himera, koji označava organizam koji se sastoji od genski različitih tkiva (Hine i Martin, 2008, 319 i 124). Hibridni organizmi imaju „srednja” obilježja (primjerice zebroid sliči na djelomično prugastoga konja), a svaka im se stanica sastoji od mješavine kromosoma roditeljskih vrsta. Dobar primjer hibrida je zebroid (Equus zebra, Equus caballus), koji je križanac između zebre i neke od

* Izv. prof. dr. sc. Tonći Kokić, Filozofski fakultet Sveučilišta u Splitu, Hrvatska. Adresa: Poljička cesta 35, Split, Hrvatska. E-adresa: tkokic@ffst.hr 
vrsta iz roda Equus (konj, magarac). Himere su pak "mozaički" organizmi sastavljeni od mješavina genski različitih stanica koje zadržavaju vlastitu gensku uputu: primjeri himere su mitska bića minotaur i kentaur: to su organizmi sastavljeni od dijelova različitih bića, kod kentaura tijelo konja s ljudskom glavom i dijelom tijela. U stvarnosti su već stvoreni embriji himere čovjeka i zeca te svinje i čovjeka, a neki eksperimenti koji se tek trebaju odviti predviđaju miševe koji bi proizvodili ljudske reproduktivne stanice.

Mogućnost hibridizacije čovjeka i nekoga od majmuna intrigantna je ideja, za mnoge je privlačna ili odbojna, no za neke je »njezina znanstvena važnost usporediva s istraživanjem mjeseca ili prvom transplantacijom srca« (Rosiianov, 2002, 279). Kako je to pitanje ipak mnogo više od znanstvenoga problema, sasvim je razumljivo da se rasprava vodi i ideološkim pojmovnim „oružjem”. Mnogi su zamišljali takve hibride, od prirodnjaka do umjetnika, od Linnéa (Linnaeus, 1758; 1771) i Buffona (1776) do Høega (1996). Prvi dobro evidentirani pokušaji su nizozemskoga biologa Moensa iz razdoblja od 1905. do 1908. (Moens, 1908) i njemačkoga stručnjaka za umjetnu oplodnju Hermanna Rohledera, koji je vjerovao da da bi uspješna hibridizacija tih vrsta bila ključni dokaz evolucije (Rossiianov, 2002, 292). Ipak, najpoznatiji primjer pokušaja hibridizacije čovjeka i antropoidnih ili čovjekolikih majmuna višestruki su neuspješni eksperimenti ruskoga profesora Ilije Ivanoviča Ivanova (1870.-1932.), koji je 1926. započeo s umjetnom oplodnjom čovjeka s jedne te čimpanza i orangutana s druge strane (Rossiianov, 2002, 278). Ponegdje se mogu naći vijesti da su slični eksperimenti izvedeni u Kini 1967. te da namjeravaju nastaviti s njima jer nema fizioloških prepreka hibridizaciji (McNulty, 1981), kao i nepouzdane, vjerojatno izmišljene, objave u tabloidima o uspješno izvedenoj hibridizaciji u SAD-u početkom 20. stoljeća.

Ivanovičev eksperiment tako ostaje jedini jasno potvrđeni pokušaj hibridizacije čovjeka s antropoidnim majmunima:

Ivanov je usjemenio tri ženke čimpanze ljudskim sjemenom, ali nije dobio hibride [...] u više navrata je pokušao umjetno oploditi žene dobrovoljke sjemenom Tarzana, 26 godišnjega mužjaka orangutana. Njegove pokušaje zaustavila je Sovjetska tajna policija uhićenjem 1930. godine (Rossianov, 2002, 279).

U raspravi o mogućnosti hibridizacije tih dviju vrsta iz perspektive filozofije biologije prvo treba istaknuti pojmovnu nesigurnost klasifikacije vrsta: nema sloge određuje li vrstu sličnost između njezinih članova ili rodoslovna povezanost u kojoj je vrsta skupina predaka i svih i samo njegovih potomaka (monofilija). Druga dva problema klasifikacije živoga svijeta tiču se taksonomskoga pluralizma, prema kojem nema jedne ispravne klasifikacije, a pravila Internacionalnoga koda nomenklature životinja (2012) drže se Linnéove (morfološke) klasifikacije, iako je ona razvijena prije Darwinove teorije evolucije, zbog čega je pogrešna (Ereshefsky, 2007, 403). Uz te pojmovne probleme, postoji preklapanje i neprecizna uporaba termina klasifikacija, taksonomija i sistematika. Ti su termini važni jer je dokazano da je hibridizacija moguća samo između dovoljno bliskih varijeteta ili vrsta. Prema tome, uspješna hibridizacija značila bi rodoslovnu bliskost 
dviju vrsta, a neuspješna suprotno. Pouzdano tumačenje ovako određuje njihov odnos: sistematika proučava odnose između organizama i svojti (plur. taxa), usmjeravajući znanstvenike u izboru taksonomskih teorija kojima biolozi klasificiraju živi svijet (Ereshefsky, 2007, 404).

Optimizam u ispitivanju moguće hibridizacije čovjeka s čimpanzom oslanja se na smještanje pretpostavljenih roditeljskih vrsta u istu porodicu Hominidae i tvrdnju o dovoljnoj bliskosti (visokom stupnju podudarnosti) njihovih genoma, pogotovo onih kodirajućih. Na uvjerenju o visokom stupnju genske podudarnosti i uvjerenju da nema važnih fizioloških poteškoća u potencijalnom stvaranju potomstva umjetnom oplodnjom razvijala se dalje ideja moguće hibridizacije tih dviju vrsta (Bourne, 1971, 5-30).

\section{Vrste i hibridi}

Hibridizacijom se dakle označava nastanak potomstva od (genski) različitih roditelja — različitih varijeteta (podvrsta) ili vrsta: »Hibrid je potomak nastao parenjem roditelja koji se razlikuju u barem jednom obilježju « (Hine i Martin, 2008, 319). Različitost obilježja roditelja pretpostavlja da je riječ o križanju jedinki iznad razine vrste, odnosno dviju različitih vrsta. Hibridi između dviju različitih vrsta, ali ipak genski i morfološki dovoljno podudarnih, dokazano su mogući, a tvore potomstvo smanjene plodnosti (primjerice nastalo križanjem kokoši i fazana) ili najčešce sterilno potomstvo. John Burdon Haldane 1922. to je objasnio heterozigotnošću spola hibridnoga potomstva i spola koji je rijedak ili sterilan (obično muški), da takav spol ima različite genske alele na homolognim kromosomima. Inače se barem neki od hibrida u prvoj generaciji (F1) u nekoj mjeri mogu dalje razmnožavati. Hibridno potomstvo ,jače” je od roditelja, otpornije na bolesti i duljega životnoga vijeka (Hine i Martin, 2008, 319). Smanjenjem plodnosti ili potpunom nemogućnošću stvaranja potomstva uspostavljena je barijera daljnjega križanja između različitih (pod)vrsta i zapriječen pritok gena u njihovu izvornu gensku zalihu (eng. gene pool). Reproduktivna izolacija jedno je od ključnih obilježja vrste u biologiji, pa iako ima gotovo neograničen broj definicija vrste (Mayr, 1982, 870), reproduktivna izolacija ključni je i trajni teorijski kriterij u široko prihvaćenom i korištenom terminu koji definira vrstu u biologiji — biološkom pojmu vrste, eng. biological species concept (BSC). Biološki pojam vrste prihvaćen je, unatoč logičkoj i instrumentalnoj manjkavosti, kao i različitim značenjima unutar različitih područja biologije. Treba razlikovati križanje populacija unutar vrste od hibridizacije, pri čemu opet treba istaknuti razliku između sterilnosti i reproduktivne izolacije vrsta: izolacijski mehanizmi vrlo su fini i sadržavaju brojne čimbenike u kojima se ne koristi mehanizam sterilnosti. Izolacijski mehanizmi označavaju granice populacija određenih vrsta u reproduktivnom razdvajanju od populacija drugih vrsta. Sistematika pak definira populaciju kao zajednicu stvarno ili potencijalno križajućih organizama određenoga područja koji imaju zajedničku zalihu gena i mogu dobiti plodno potomstvo. To znači da izolacijski mehanizmi štite gensku zalihu populacija, ali ne i svaku 
specifičnu jedinku (Mayr, 1982, 274). ${ }^{1}$ Drugo je ključno obilježje vrste njezina specifična ekološka niša: područje, klima, hrana, neprijatelji i dr. Izolacijski mehanizmi djeluju na dvije razine (Mayr, 1963, 57): na prvoj razini zapreka postoji prije samoga čina parenja između jedinki različitih vrsta (mehanička, sezonska i/ ili etološka izolacija), a na drugoj razini zapreka je u nizu mehanizama nakon parenja (nema oplodnje, smrt zigote, smanjena životnost hibrida, njegova sterilnost i/ili proizvodnja manjkavih hibrida F2). Izgleda da genska nepodudarnost ili druga vrsta neravnoteže roditelja (roditeljskih vrsta) proizvodi sterilnost potomaka, a da hibridizacija tvori neravnotežu u integraciji roditeljskih vrsta u genskom smislu i ekološkom prebivalištu nastalu dugotrajnim procesom. Darwin nije znao za gensku osnovu nasljeđivanja, ali je naslućivao njezinu narav jer je tvrdio da sposobnost križanja ne ovisi o srodstvu roditeljskih vrsta nego da je »sposobnost križanja povezana s razlikama [...] koje su nama nedostupne, a omeđene su na rasplodni sustav« (Darwin, 2000, 212). Hibridizacija u životinjskom svijetu u prirodi uvijek je iznimka: tamo gdje nema blisko srodnih vrsta podražaji i pozivi za parenje su općeniti. Međutim, u području zajedničkoga obitavanja bliskih vrsta sustavi prepoznavanja i pozivanja vrsnoga partnera suprotnoga spola (eng. specific mate recognition system, skraćeno SMRS) na parenje visoko su specijalizirani. Visoko specijalizirani podražaji parenju u takvim sredinama spadaju u izolacijske mehanizme „usmjerene” očuvanju cjelovitosti genske zalihe, morfologije i etologije te vrste. Pitanje je mogu li te dvije vrste probiti tu izolacijsku barijeru: antropološko-metafizička pretpostavka darvinizma tvrdi visok stupanj sličnosti čovjeka i antropoidnih majmuna, zadržavajući razlike na kvantitativnoj razini. U prvom izdanju knjige Systema Naturae iz 1735. Linné na temelju morfologije svrstava čovjeka i antropoidne majmune u red primata, ali i u zajedničku kategoriju Anthropomorpha (ili čovjekoliki [majmuni]) ne nalazeći među njima morfološke razlike, ${ }^{2}$ nego samo u govoru [sic!]. Sistematika od 1825 . godine smješta čovjeka i velike majmune ${ }^{3} \mathrm{u}$ istu porodicu Hominidae, iako ponekad opet smješta čovjeka u zasebnu porodicu (familia) hominida (Hominidae), a velike majmune u porodicu pongida (Pongidae) i/ili pak smješta čovjeka i običnu čimpanzu (Pan troglodytes) i bonobo čimpanzu (Pan paniscus) u istu podporodicu hominina (Homininae). Razvojem genetike raste uvjerenje da su antropoidni majmuni, osobito obična čimpanza i čovjek, najbliži srodnici koji imaju zapanjujuće visok stupanj genske podudarnosti: genska razlika između dva pojedinca ljudske vrste u prosjeku je oko $0,1 \%$, a jedna studija tvrdi da je razlika između istih aspekata genoma čimpanze i čovjeka 1,6\% (Smithsonian, 2019), ili čak samo 0,6\% (Wildman, 2003, 7181-7183). Drugačiji izračuni bitno su različiti jer navode gensku razliku od $4-5 \%$, tvrdeći da je »prema njihovim istraživanjima bolja procjena da

1 Zbog statističke naravi izolacije Mayr je "morao" mijenjati definiciju vrste.

2 Linné je u rod Homo svrstavao još jednu ljudsku vrstu, špiljskog čovjeka ili Homo troglodytes (Koerner, 1999, 87), a potom i vrstu Homo lar (Vigors, 1832, 136).

3 Tu spadaju dvije vrste gorila iz roda Gorilla, dvije vrste orangutana iz roda Pongo i dvije već spomenute vrste čimpanzi. Ponegdje se u sistematici nalaze i drugačije klasifikacije koje nalaze po samo jednu vrsta iz rodova Gorilla i Pongo. 
je 95\% parova baza podudarno u čimpanze i čovjeka« (Britten, 2002, 13633). Neovisno o tim razlikama čovjeku je čimpanza genski najsličnija vrsta, a razvoj umjetne oplodnje stavlja u drugi plan izolacijske mehanizme parenju: novo pitanje je može li se umjetno hibridizirati te dvije vrste.

\section{Geni i genocentrizam}

Tvrdnja o 99\% genskoj sličnosti dviju vrsta čini se razarajuća po sumnju u mogućnost hibridizacije. Ova tvrdnja je metodološki vrlo slaba i nepouzdana jer nikada nije provedena usporedba kompletnih genoma dviju vrsta. Vjerojatno najopsežnije poznato komparativno proučavanja dvaju genoma obuhvaća svega $1 \%$ tih genoma, ${ }^{4}$ nalazeći velike razlike između dvaju genoma (Fujiyama et al., 2002, 131). ${ }^{5}$ Još važnije, nalaz je ukazivao da je ljudski genom „pokriven” s $48.6 \%$ nukleotidnih sekvenci (BACs) ${ }^{6}$ čimpanze, a taj je postotak najmanji kod Y kromosoma (manje od 5\%). Štoviše, čak ni projekt ljudskoga genoma nije obuhvatio heterokromatinska područja, koja čine oko $8 \%$ ljudskoga genoma. Pri tom opet, treba znati da se smatra da oko $97 \%$ DNK u eukariota nema funkciju kodiranja gena (Tamarin, 1999, 413), a u ljudi možda tek oko 1,5\% gena kodira bjelančevine. Projekt genoma čimpanze pokazao je da se ljudska stanica od čimpanzine, čak i kada se govori o samo 1,23-3\% nepodudarnosti, razlikuje u 35 milijuna parova baza DNA, a drugih 5 milijuna parova baza razlikuju se umetanjem ili brisanjem te kromosomskim razmještajem (kao i brojem kromosoma) (Cooper i Kehrer-Sawatzki, 2008, 1 i 6). Razlika u broju kromosoma, 23 para u čovjeka i 24 para u čimpanze, ne čine se smetnjom jer se uspješno hibridiziraju vrste $s$ različitim brojem kromosoma: domaće kokoši (Gallus domesticus), koja ima 39 parova kromosoma, s fazanom (Phasianus colchius), koji ima 41 par kromosoma (Muir i Aggrey, 2003, 573) te najpoznatije hibridizacije magarca (Equus asinus) s 31 parom kromosoma i konja (Equus cabalus), koji ima 32 para kromosoma. Usporedno proučavanje kromosoma u čimpanze i čovjeka pokazalo je gotovo istovjetnost 18 kromosomskih parova, a razlika u broju kromosoma objašnjava se »udruživanjem dvaju različitih akrocentričkih kromosoma u zajedničkoga pretka stapanjem u veliki submetacentrički ljudski kromosom broj 2« (Samonte et al., 1998, 41). Ti su autori radi utvrđivanja porijekla ljudskoga kromosoma 2 pokušali hibridizirati taj ljudski kromosom s kromosomima čimpanze, gorile i orangutana, ali bez uspjeha (Samonte et al. 1998, 41). Položaji gena na tim kromosoma u čovjeka i antropoidnih majmuna čine se istovjetnima (eng. synteny), ${ }^{7}$ no to ne znači

4 U tom usporednom istraživanju proučavao se čimpanzin kromosom 22 (PTR22) i ortologni (odgovarajući) ljudski kromosom 21 (HSA21). Ljudski kromosom 21 (HSA21) reprezent je ljudskoga genoma jer je najbolje proučen.

5 Ovi autori su pokretači Međunarodnoga konzorcija za sekvenciranje kromosoma 22 čimpanze (The International Chimpanzee Chromosome 22 Consortium).

6 BACs je skraćenica za sekvencu bakterijskoga umjetnoga kromosoma.

7 Usp. grafički prikaz položaja gena na kromosomu 2 čovjeka i čimpanzinih kromosoma $2 \mathrm{~A}$ i 2B: Ensembl Human, 2019. 
nužno njihovu evolucijsku povezanost, iako se tako činilo 1991. kad je izvedeni pokus tumačio nastanak ljudskoga kromosoma 2 spajanjem dvaju predačkih majmunskih kromosoma (Ijdo et al., 1991, 9051). Naime, taj je eksperiment umjesto očekivane fuzije satelitskih komponenti ukazao na telomeri-telomeri DNK fuziju DNK sekvence (2 do 30 kilobaza dvolančanih TTAGGG) ljudskoga kromosoma 2. Međutim, do sada poznati načini fuzije u životinja uključuju satelitske komponente DNK (Tamarin, 1999, 411), tako da se spajaju satDNK (satelitske DNK) sa satDNK ili satDNK s telomernom DNK. Fuzija tipa telomeri-telomeri DNK do sada nije zabilježena osim kod oštećenih DNK jer telomeri štite kromosom od spajanja i rekombinacije (Blasco et al., 1997), a to bi moglo ukazivati na aktivnost telomera koji su inače neaktivni. To je zanimljivo jer je aktivnost telomera povezana s kancerogenim rastom stanica (Tamarin, 1999, 413), tako se kod 80-90\% tumora uočava aktivnost telomera. Nadalje, telomeri kod ljudi izrazito su kraći nego kod čimpanzi i imaju svega 10 kilobaza DNK, a u čimpanzi je to 23 kilobaze DNK. U revidiranom izvještaju Međunarodnoga konzorcija za sekvenciranje čimpanzinoga kromosoma 22 iz 2004., objavljenoga u časopisu Nature, piše:

Usporedbom cijele sekvence ${ }^{8}$ s odgovarajućim ljudskim kromosomom, 21, pronašli smo da se $1.44 \%$ kromosoma sastoji od supstitucije jedne baze uz gotovo 68.000 umetanja ili brisanja nukleotida. Te su razlike dovoljne za izazivanje promjena u većini bjelančevina. Zaista, $83 \%$ od 231 kodirajuće sekvence, uključujući funkcionalno važne gene, pokazuje razliku aminokiselina na razini sekvenci. [...]. Ti podatci sugeriraju da su biološki učinci genskih razlika puno kompliciraniji nego se prije mislilo (Watanabe et al., 2004, 382 i 388).

Ovdje je jasno napuštanje ideje o genskoj istovjetnosti ili njezinu značenju po (morfološko/rodoslovnoj) povezanosti. Metodologija utvrđivanja podudarnosti genoma tu se ne dovodi u pitanje, makar, ona bi mogla biti ključni dio argumentacije u toj raspravi. Ako bi dakle metodologiju tih istraživanja ostavili po strani, genska razlika između čovjeka i čimpanzi bila bi manja nego čovjeka i bilo koje druge životinjske vrste (iako nisu rađene detaljne usporedbe). Iz perspektive evolucijske biologije i njezine suvremene sinteze, objašnjenje fenotipske evolucije oslanja se na genske varijacije unutar i između populacija (Laubichler, 2009, 204), pa bi visoki stupanj genske sličnosti posljedično značio visok stupanj sličnosti ostalih obilježja, a najprije fenotipskih. Prema tom genocentičkom tumačenju fenotip je samo pasivni nusproizvod evolucijskih procesa upravljanih unutarnjim genskim uputama (genske varijacije) i vanjskim prirodnim odabirom. Kako to nije slučaj jer postoje bitne morfološke razlike između tih vrsta (u sljedećem su poglavlju opisane ključne, supstancijalne fenotipske razlike), potrebno je vidjeti zašto. Evo-devo teorija ${ }^{9}$ (eng. evolutionary development) ključnim nalazi regulaciju ekspresije gena, a ne genske upute ili promjene. Da je tako, potvrđuje

8 Tj. kromosoma 22 čimpanze.

9 Sporno je spada li Evo-Devo unutar paradigme suvremene sinteze ili osporava tu paradigmu. Usp. Labichler, 2009. 
otkriće manje genske razlike u usporednih vrsta nego se mislilo. Dakle fenotipske razlike nastaju promjenom obrasca ekspresije gena, a ne novim genima. Kod čimpanze i čovjeka je slično jer su usporedna istraživanja na tkivima dviju vrsta pokazala da se genska ekspresija mijenjala učestalije kod čovjeka, pogotovo u tkivu mozga, gdje se pokazala nerazmjerna razlika ekspresije gena i promjene aminokiselina (Khaitovich, 2005, 1853). Usporedne su studije pokazale i da stanice tkiva mozga cerebralnoga korteksa u čovjeka, za razliku od stanica mozga čimpanzi, iako sličnoga tipa i rasporeda, trebaju 50\% dulje vrijeme za metafazu (diobu stanica), zbog čega je možda mozak čovjeka tri puta veći od čimpanzina i doprinosi većim spoznajnim sposobnostima (Mora-Bermúdez et al., 2016).

Tako, u nekoj mjeri slični genomi ekspresijom gena tvore strukturno velike fenotipske razlike i funkcionalno radikalno drugačije organizme. Očito se slično događa i u dvije ovdje razmatrane vrste.

\section{Morfologija}

Na prvi pogled morfologije čovjeka i čimpanze čine se sličnima, međutim, razlike među njima su supstancijalne. Filozofska antropologija kao filozofska disciplina prva je pokušala ustanoviti jedinstvenu znanost o čovjeku, uviđajući da pojedine znanosti (biologija, fiziologija, medicina, pravo i dr.) zahvaćaju samo segmente koji tek sabrani u jednu znanost mogu ukazati na narav čovjeka. Filozofijska je antropologija pokazala da čak i kada bi ostavili po strani nadživotinjske strukture čovjeka (jezik, tehniku, kulturu, moral, religiju, pravo, kuhanje hrane, regulirane odnose između muškaraca i žena i dr.) čovjekova morfologija bila bi specifična, i u usporedbi sa životinjskom morfologijom pokazuje krucijalnu različitost. Pri tom, ovdje nabrojene antropine ili specifičnosti čovjeka treba shvatiti skupno: svi zajedno sabrani čine čovjeka posebnim. Moguće je naći bića koja grade nastambe i tvore društva s podjelom rada (pogotovo u kukaca), koja komuniciraju (primjerice morski sisavci), ali nigdje u životinjskom svijetu nema vrsta u kojih bi se mogle naći sve gore nabrojene osobine. Pa i pojedinačno, između komunikacije morskih sisavaca i čovjeka nepremostiva je pukotina složene gramatike i jezičnoga bogatstva, koje postoji već u najprimitivnijih plemena, a između tehnike čimpanze u hvatanju termita slamčicom i nuklearne podmornice je slično (i na puno manjoj razini je tako jer samo čovjek izrađuje oruđa za još nepostojeću potrebu i prenosi ih na udaljena mjesta).

Na općoj poredbenoj razini, čovjekovu morfologiju obilježava manjkavost i primitivnost: čovjek nije biološki zaštićen od klimatskih uvjeta, nema napadačkih organa ni onih za bijeg, zubalo mu je neodređeno (ni biljojeda ni mesojeda), instinkti manjkavi $\mathrm{i} »$ ni u jednom određenom segmentarnom miljeu nije prirodno sposobno za život «(Gehlen, 2005, 31). Čovjek tako u morfološkom smislu nema visoko specijaliziranih organa, nego su oni ontogenetski i rodoslovno primitivni: odrasli čovjek trajno zadržava fetalna razvojna stanja i organe koji su „konstrukcijski” na početku — arhaični: primitivni, nespecijalizirani i geološki stari. Mit o Epimeteju i Prometeju iskazivao je svijest o toj ljudskoj specifičnoj situaciji: 
Epimetej je sve "specijalizacije" iskoristio za opskrbu životinja, ostavivši čovjeka na nemilost silama prirode. Prometej je zato, da bi spasio čovjeka, ljudima dao ukradenu božansku vatru (uma, lógos). Za razliku od svih drugih živih bića prilagođenih okolišnoj prirodi, priroda čovjeku predstavlja opasnost kojoj se on ne može prilagoditi, nego prirodu nužno prilagođava sebi.

Na posebnoj razini, u usporedbi s antropoidnim majmunima, čovjeka izdvaja smještenost zubala ispod mozga (ortognatizam), oblik donje vilice, nedlakavost, gubitak pigmenta u koži, kosi i očima, oblik i veličina unutrašnjega uha, položaj foramen magnum, velika zapremina lubanje i težina mozga, kasno zarastanje šavova lubanje, građa šake i stopala, funkcionalno povezani bipedalizam te niz drugih razlikovnih funkcija. Uz bipedalizam, uspravljenost tijela i položaj glave zahtijevali su (i omogućavali) strukturu vizualnosti vezanu uz vertikalnu osnovnu orijentaciju u prostoru. Suprotno tomu, majmuni koji žive na drveću stalno mijenjaju os opažanja i ne mogu shvatiti statiku predmeta. Proučavanje je pokazalo razliku između oblika i relativne veličine ${ }^{10}$ (u usporedbi s veličinom tijela) polukružnih kanalića unutrašnjega uha čovjeka i čimpanze odgovornih za ravnotežu, što može biti povezano s načinom kretanja (bipedalizam) i (uspravnim) položajem tijela: tek se kod Homo erectus prvi put nalazi čovjekolika struktura unutrašnjega uha. Wolfgang Köhler je u knjigama Intelligenzprüfungen an Anthropoiden (1917.) i Intelligenzprüfungen an Menschenaffen (1921.) opisao pokuse s čimpanzama u kojima je utvrđen nedostatak shvaćanja vertikalne statike: čimpanze su pokušale dohvatiti visoke predmete (hranu) krpom, lijepljenjem kutija na zid, vađenjem iz naslaganih kutija one donje i njezinim postavljanjem na već postavljene ili postavljanjem kutije uz zid. Trajno očuvana embrionalna struktura i primitivnost čovjekove morfologije ima tri posebnosti: glava, ruka (šaka) i stopalo (Gehlen, 2005, 80-90). Kod antropoida su fetalni oblici lubanje u mladosti u visokoj mjeri slični ljudskoj glavi, ali se ta sličnost ranih (starijih) embrionalnih stanja kasnije gubi radi zadržavanja fetalnih stanja u čovjeka i specijalizacije u majmuna. Slično je s rukom čovjeka jer je u majmuna jasna usmjerenost prema specijalizaciji života na stablu: dugi prednji i kratki stražnji udovi, a obrnuto kod čovjeka, kojemu je dužina ruke $60 \%$ dužine noge, kao i stopalo koje se specijalizira u oruđe slično prednjim ekstremitetima, sa skraćenim palcima, prikladno za kvačenje, držanje i penjanje. Majmuni tako hodaju na četiri šake, a dvonožni hod zahtijeva ravno stopalo. Razlika proporcija dvaju morfologija mogla bi se jasno predstaviti ako bi u kvadrat i kružnicu Vitruvijeva čovjeka ucrtali čimpanzu. I u probavnom sustavu "postoje bitne razlike u razmjeru duljine crijeva « (Watkins et al., 2010, 1) jer čovjek ima dulje tanko crijevo (56-67\% svih crijeva u čovjeka prema 23-28\% u čimpanza), a kraće debelo crijevo (17-23\% svih crijeva u čovjeka prema 52-54\% u čimpanze). Također, ljudi imaju manji volumen crijeva s obzirom na tjelesnu masu nego čimpanze (Watkins et al., 2010, 1). Kraća i volumenski manja crijeva povezana su uz metaboličku „cijenu” potrošnje energije većega mozga, ljudi troše više energije od čimpanzi (eng. total energy expenditure,

10 Kod čovjeka još postoji spolni dimorfizam vezan uz oblik i veličinu kanalića, a u čimpanza ne. 
TTE) i imaju bitno veći postotak tjelesne masti od čimpanzi (22,9\% prema 8,4\% za muške jedinke), tvrde Pontzer et al. (2016). Mozak sam na vrhuncu potrošnje, u djetinjstvu čovjeka, troši $43 \%$ dnevne energetske potrošnje ili $66 \%$ cijeloga metabolizma tijela u mirovanju (Kuzawa et al., 2014, 13010). Uz te razlike, postoje i razlike u obliku zdjelice i rebara: prvo jer je glava ljudskoga fetusa bitno veća i treba veći porođajni kanal, ${ }^{11}$ a drugo, uz kralježak manje (32) čimpanze imaju jedno rebro više (13) i drugačiji torakalni „kavez”. Torakalni kavez je u ljudi širi, zaobljeniji i usmjeren na gravitacijski centar prema (S) zaobljenoj kralježnici, dok je u čimpanza „bačvast”, a kralježnica ravna, poput rampe mosta na koju je moguće vješati utege, a bitna je razlika i u vratu. Linné je jedinu razliku između čovjeka i čimpanze nalazio u govoru, no ona je i morfološki uvjetovana: grkljan je u čovjeka smješten nisko u grlo, a čimpanze imaju vrećice zraka koje omogućavaju glasne zvukove, ali bez fiziološke osnove za pravi govor. Nisko smješteni grkljan omogućava »fleksibilnost jezika i specifičan kut jezika u vokalnom traktu, što povećava raspon varijacija rezonantskih ${ }^{12}$ frekvencija (Belin, 2006, 2094). Možemo reći da je čovjek, za razliku od čimpanzi, opskrbljen ne samo softverom, nego i hardverom za govor. Hardverski dio, mozak, uz Brocino i Wernickeovo područje, ukazuje na manju relativnu razliku u gustoći neurona (1,25 puta više u čovjeka po kubičnom centimetru), ali i na veliku apsolutnu razliku u broju neurona: 30 milijardi u čovjeka u odnosu na 6 milijardi u čimpanzi. Na kraju, tu je svijest (o vlastitoj svjesnosti) kao posebnost čovjeka.

\section{Nespojivost osobina dviju vrsta}

Hibridni organizmi nastaju parenjem roditelja koji se razlikuju u barem jednom obilježju (Hine i Martin, 2008, 319), a to obilježje može biti gensko, morfološko ili rodoslovno. Dakle, mora postojati genska i/ili morfološka razlika između roditelja da bi potomstvo nazvali hibridnim, ali ne smije biti prevelika da ga spriječi - raspon mogućih roditelja mora biti iznad (sub)populacija iste vrste, križanje mora biti između dviju genski i morfološki blisko srodnih jedinki, ali različitih vrsta. Uspješna hibridizacija potvrdila bi gensku, morfološku i rodoslovnu bliskost roditeljskih vrsta. Dugotrajni neuspjeh u tome bi upućivao na suprotno.

Pretpostavljeni hibridni potomak čovjeka i čimpanze (i/ili druge vrste antropoidnih majmuna) morao bi nastati oplodnjom ženske gamete jedne vrste muškom gametom druge vrste, tvoreći zigotu. Zigota je diploidna stanica koja sadrži dva seta kromosoma: u slučaju čovjeka stopi se haploidni set 23 majčina kromosoma s haploidnim setom 23 očeva kromosoma, tvoreći konačno diploidnu zigotu koja sadrži 46 kromosoma. U proučavanom slučaju diploidna zigota trebala bi

11 Kod ljudi žene imaju menstrualni ciklus u dvije faze i jajnici stalno luče hormone, a kod ženki primata postoje četiri faze s estrusom, koji jedini omogućava kopulaciju.

12 Varijacije rezonantskih frekvencija određuju fonetsku kakvoću samoglasnika. Vokalni trakt uzrokuje rezonancije-formante, pojačani dio spektra gdje zrak iz pluća u govornom prolazu istodobno rezonira različitim frekvencijama. 
spojiti dva nejednaka kromosomska seta, jednoga od 23 i jednoga od 24 kromosoma, tvoreći u pretpostavljenom potomstvu možda kromosomski set od 47 kromosoma. Razlika kromosomskih brojeva ne mora biti prepreka hibridizacijskomu križanju vrsta, ali niti istovjetnost kromosomskih brojeva nije prednost sama po sebi. U suprotnom, Homo sapiens bi mogao lako hibridizirati s malim azijskim jelenom (Muntiacus reevesi) ili čak jednom vrstom raka (Parhyale hawaiensis), koji također imaju 46 kromosoma. Ako bi prepreka različitoga kromosomskoga broja ipak bila uspješno svladana, ostali bi drugi izolacijski mehanizmi: prije i poslije pokušaja oplodnje. Čak i kada bi pretpostavili umjetnu oplodnju i zanemarili izolacijske mehanizme prije moguće prirodne oplodnje, poput mehaničke izolacije (mehanička nemogućnost kopulacije ili uspješna kopulacija bez transfera sjemena), sezonske izolacije (potencijalni spolni partneri se ne susreću), etološke izolacije (potencijalni partneri se susreću, ali se ne pare), ostalo bi otvorenim pitanje (ne)mogućnosti biokemijske reakcije prepoznavanja jajašca i spermija. Ta bi se poteškoća možda mogla zaobići skidanjem zaštitnoga pokrova s jajašca ili izravnim umetanjem spermija u jajašce. Dvojba o mogućnosti uspješnog spajanja spolnih kromosoma ostaje upitna jer je podudarnost Y kromosoma dvaju vrsta tek 4,8\%,13 iako je podudarnost i kod X kromosoma neočekivano mala i iznosi tek 25,4\% (Fujiyama et al., 2002, 133). Izvori napominju moguću metodološku slabost u usporedbi X kromosoma, ali za malu podudarnost Y kromosoma nemaju objašnjenje: »možemo samo spekulirati zašto je tako mala podudarnost « (Fujiyama et al., 2002, 133). Prema tome, stupanj je genske sličnost u tom ključnom detalju za oplodnju dvaju vrsta upitan, kao i uloga cjelokupne genske sličnosti u izgradnji sličnih fenotipova: sve više se otkriva da su za izgradnju fenotipa ključni obrasci ekspresije gena, a ne novi ili različiti geni (Laubichler, 2009, 204).

Taksonomski aspekt hibridizacije morao bi zrcaliti (gensku i) morfološku sličnost, odnosno razliku, a hibridno potomstvo nasljeđuje „srednja” obilježja svojih roditelja: zebroid koji sliči na djelomično prugastog konja, mulu i mazgu koje su genski i morfološki negdje između konja i magarca i sl. U slučaju čovjeka i čimpanze hibridni potomak trebao bi imati miješana morfološka obilježja roditeljskih vrsta: s jedne strane bi stajala nespecijalizirana ljudska morfologija, kratke ruke i dugačke noge, uspravan hod i zakrivljena kralježnica, velika lubanja i mozak, ortognatizam s uvučenom bradom, nisko smješteni grkljan. S druge strane strane stoji specijalizirana morfologija čimpanze, dugačke ruke i kratke noge, četveronožno kretanje (kada je na zemlji), zaobljene kosti nogu i ravna kralježnica, mala lubanja i mozak, izbačena čeljust, visoko smješteni grkljan i drugo. Već taj sažeti popis morfoloških razlika dviju vrsta ukazuje na veliku razliku morfoloških osobina i generalnu nespojivost oblika. Hibridni bi potomak na morfološkoj razini morao imati mješavinu specijaliziranih životinjskih i nespecijaliziranih ljudskih osobina. Preciznije, takvo biće moralo bi imati kontradiktorna, isključujuća

13 Podudarnost kod Y kromosoma je u 1.027 kilobaza od 23.055 testiranih, a kod X kromosoma u 34.991 od proučavanih 137.753 . 
obilježja čovjeka i životinje, a to nije logički moguće. ${ }^{14}$ Kada bi se uz te osobine razmatrali proizvodi ljudskoga duha, neovisno smatra li se taj ontološki zbiljskim ili metaforom, i bez obzira objašnjava li netko jezik, moral, religiju, pravo, tehniku, umjetnost, samosvijest i druge antropine redukcionistički kao puke epifenomene materije u gibanju - otkriva se nespojivost dvaju vrsta. Pretpostavljeni hibrid otkriva se kao biće protivnih osobina, proturječno u sebi, pa ga se jedino može svrstati skupinu u koju je Linné svrstavao apsurdne, nemoguće ili mitske životinje, unutar skupine vrsta Animalia paradoxa.

\section{Zaključak}

Pretpostavka moguće uspješne hibridizacije čovjeka i neke od vrsta antropoidnih majmuna temelji se na uvjerenju o relativno visokom stupnju genske i morfološke sličnosti dviju vrsta i relevantnosti tih sličnosti. Međutim, obje se te sličnosti rastvaraju u relativno nevažnom stupnju genske sličnosti te genskoj nerelevantnosti uočenoga stupnja sličnosti i prividnosti morfološke sličnosti već u površnom proučavanju osobina dviju vrsta i njihovoj usporedbi. Suvremena genetika pokazuje puno veću gensku različitost nego se mislilo u početku usporedbe njihovih genoma (90-tih 20. stoljeća). Također je pokazano da su fenotipske razlike više rezultat promjene obrasca (ekspresije) gena nego novih gena i da je njihova genska sličnost nedostatna za fenotipsku sličnost. Prema tomu, slabi relevantnost genske sličnosti za određivanje hibridizacijskoga potencijala. Također, slika prividne morfološke sličnosti raspada se u nepremostivu pukotinu između specijaliziranosti majmuna i nespecijalizirane morfologije i organa čovjeka, logički i ontološki. Zamišljanje srednjih osobina dvaju tako oprečnih bića, s kontradiktornim obilježjima, ukazuje na nemogućnost uspješne hibridizacije tih vrsta, ostavljajući takvu mogućnost samo unutar mitskoga i magičnoga bestijarija, unutar Linnéove skupine apsurdnih vrsta, vrsta označenih kao Animalia paradoxa.

\section{Literatura:}

Belin, Pascal (2006). Voice processing in human and non-human primates. Philosophical Transactions of the Royal Society of London: Series B: Biological Sciences Royal Society, 361(1476), 2091-2107.

Blasco, M. Antonio; Lee, Han-Woong; Hande, M. Prakash; Samper, Enrique; Lansdorp, M. Peter; DePinho, Ronald; Greider, W. Carol (1997). Telomere shortening and tumor formation by mouse cells lacking telomerase DNA. Cell, 91, 25-34.

Bourne, Geoffrey (1971). The Ape People. New York: G. P. Putnam's Sons.

Britten, J. Roy (2002). Divergence between samples of chimpanzee and human DNA sequences is 5\% counting indels. Proceedings of the National Academy of Sciences, 99, 13633-13635.

14 Kada imamo sudove A $\mathrm{i} \neg \mathrm{A}$, tada samo jedan od njih može biti istinit, ontološki prisutan, jedan jest, a drugi nije. Ovdje bi to značilo da nije moguća mješavina A i $\neg$ A, specijalizirano i $\neg$ specijalizirano, nego jedno ili drugo. Miješanje boja koje nalazimo u nekih hibrida ili mješavina rasa nije isto: riječ je o miješanju boja, a kontradikcija bi bila primjerice crna i $\neg$ crna (to nije bijela), a to je boja i $\neg$ boja. 
Buffon, Georges Louis Leclerc (1776). Histoire naturelle, générale et particulière. Vol. 14. Paris: Imprimerie Royale.

Cooper, David; Kehrer-Sawatzki, Hildegard (2008). The Chimpanzee Genome Project. Chichester: John Wiley \& Sons Ltd.

Darwin, Charles (2000). Postanak vrsta putem prirodnog odabira ili očuvanje povlaštenih rasa u borbi za život. Zagreb: Naklada Ljevak.

Ensembl Human (2019). Synteny between Human chromosome 2 and Chimpanzee. URL: http://www.ensembl.org/Homo_sapiens/Location/Synteny? $\mathrm{db}=$ core;otherspe cies $=$ Pan_troglodytes; $r=2: 206444782-206544782$ (24.03.2019.)

Ereshefsky, Marc (2007). Species, Taxonomy and Systematics. U: Mohan Matthen i Christoper Stephens (ur.), Philosophy of Biology (str. 403-427). Amsterdam: Elsevier B. V.

Fujiyama, Asao; Watanabe, Hidemi; Toyoda, Atsushi; Taylor, D. Todd; Itoh, Takehiko; Tsai, Shih-Feng; Park, Hong-Seog; Yaspo, Marie-Laure; Lehrach, Hans; Chen, Zhu; Fu, Gang; Saitou, Naruya; Osoegawa, Kazutoyo; de Jong, J. Pieter; Suto, Yumiko; Hattori, Masahira; Sakaki, Yoshiyuki (2002). Construction and Analysis of a Human-Chimpanzee Comparative Clone Map. Science, 295(5552), 131-134.

Gehlen, Arnold (2005). Čovjek: njegova narav i položaj u svijetu. Zagreb: Naklada Breza.

Hine, Robert; Martin, Elizabeth (ur.) (2008). A Dictionary of Biology. Oxford: Oxford University.

Høeg, Peter (1996). The Woman and the Ape. London: The Harvill.

Ijdo, W. Jacob; Baldini, Antonio; Ward, C. David; Reeders, T. Stephen; Wells, A. Richard (1991). Origin of human chromosome 2: An ancestral telomere-telomere fusion. Proceedings of the National Academy of Sciences, 88(20), 9051-9055.

International Code Of Zoological Nomenclature (2012). The International Trust for Zoological Nomenclature 1999. London: The Natural History Museum. URL: http:// www.iczn.org/iczn/index.jsp (20.9.2018.)

Khaitovich, Philipp; Hellmann, Ines; Enard, Wolfgang; Nowick, Katja; Leinweber, Marcus; Franz, Henriette; Weiss, Gunter; Lachmann, Michael; Pääbo, Svante (2005). Parallel patterns of evolution in the genomes and transcriptomes of humans and chimpanzees. Science, 309, 1850-4.

Koerner, Lisbet (1999). Linnaeus: Nature and Nation. Cambridge, MA: Harvard University.

Kuzawa, W. Christopher; Chugani, T. Harry; Grossman, I. Lawrence; Lipovich, Leonard; Muzik, Otto; Hof, R. Patrick; Wildman, E. Derek; Sherwood, C. Chet; Leonard, R. William; Lange, Nicholas (2014). Metabolic costs and evolutionary implications of human brain development. Proceedings of the National Academy of Sciences of the United States of America, 111(36), 13010-13015.

Laubichler, D. Manfred (2009). Evolutionary Developmental Biology Offers a Significant Challange to the Neo-Darwinian Paradigm. U: Francisco Ayala i Robert Arp (ur.), Contemporary Debates in Philosophy of Biology (str. 199-212). Malden, MA: Blackwell.

Linnaeus, Carolus ( $\left.{ }^{10} 1758\right)$. Systema naturce per regna tria naturce, secundum classes, ordines, genera, species, cum characteribus, differentiis, synonymis, locis. 1. Stockholm: Laurentius Salvius.

Linnaeus, Carolus (1771). Mantissa plantarum altera generum editionis VI et specierum editionis II. Stockholm: Laurentius Salvius.

Mayr, Ernst (1963). Animal Species and Evolution. Cambridge, MA: Harvard University.

Mayr, Ernst (1982). The Growth of Biological Thought. Diversity, Evolution and Inheritance. Cambridge, MA: Harvard University. 
McNulty, Timothy (1981). Chinese Aim To Implant Human Sperm In Chimps. St. Petersburg Independent, 12 February, 19.

Moens, H. M. Bernelot (1908). Truth: Experimental Researches about the Descent of Man. London: A. Owen.

Mora-Bermúdez, Felipe; Badsha, Farhath; Kanton, Sabina; Camp, J. Gray; Vernot, Benjamin; Köhler, Kathrin; Voigt, Birger; Okita, Keisuke; Maricic, Tomislav; He, Zhisong; Lachmann, Robert; Pääbo, Svante; Treutlein; Barbara; Huttner, B. Wieland (2016). Differences and similarities between human and chimpanzee neural progenitors during cerebral cortex development. Elife. URL: https://elifesciences.org/articles/18683 (20.9.2018.)

Muir, M. William; Aggrey, E. Sammy (ur.) (2003). Poultry Genetics, Breeding and Biotechnology. Wallingford: CABI.

Pontzer, Herman; Brown, H. Mary; Raichlen, A. David; Dunsworth, Holly; Hare, Brian; Walker, Kara; Luke, Amy; Dugas, R. Lary; Durazo-Arvizu, Ramon; Schoeller, Dale; Plange-Rhule, Jacob; Bovet, Pascal; Forrester, E. Terrence; Lambert, V. Estelle; Thompson, Melissa Emery; Shumaker, W. Robert; Stephen R. Ross, R. Stephen (2016). Metabolic acceleration and the evolution of human brain size and life history. Nature, 533(7603), 390-392.

Rossiianov, Kirill (2002). Beyond Species: Il'ya Ivanov and His Experiments on CrossBreeding Humans with Anthropoid Apes. Science in Context, 15(2), 277-316.

Samonte, Rea; Ramesh, Kodavatiganti; Verma, Ram (1998). Origin of human chromosome 2 revisited. Journal of Genetics, 77(1), 41-44.

Smithsonian (2019). Genetics. U: Smithsonian, Human Evolution Evidence. URL: http:// humanorigins.si.edu/evidence/genetics (24.03.2019.)

Vigors, A. Nicholas (ur.) (1832). The Zoological Journal: Vol. 5. Bloomsbury: G. B. Sowerby.

Tamarin, Robert (1999). Principles of Genetics. Boston: WCB McGraw-Hill.

Watanabe, Hajime; Fujiyama, Asao; Hattori, Masahira; Taylor, Todd; Toyoda, D. Atsushi; Kuroki, Yoko; Noguchi, Hideki; BenKahla, Alia; Lehrach, Hans; Sudbrak, Ralf; Kube, Michael; Taenzer, Simone; Galgoczy, Petra; Platzer, Matthias; Scharfe, Maren; Nordsiek, Gabriele; Blöcker, Helmut; Hellmann, Ines;Khaitovich, Philipp; Pääbo, Svante; Reinhardt, Richard; Zheng, H.-J.; Zhang, X.-L.; Zhu, G.-F.; Wang, B.-F.; Fu, G.; Ren, S.-X.; Zhao, G.-P.; Chen, Z.; Lee, Y.-S.; Cheong, J.-E.; Choi, S.-H.; Wu, K.-M.; Liu, T.-T.; Hsiao, K.-J.; Tsai, S.-F.; Kim, C.-G.; OOta, Satoshi; Kitano, Takashi; Kohara, Yuji; Saitou, Naruya; Park, H.-S.; Wang, S.-Y.; Yaspo, Marie-Laure \& Sakaki, Yoshijuki (2004). DNA sequence and comparative analysis of chimpanzee chromosome 22. Nature, 429, 382-388.

Watkins, A. Paul; Moser, B. Moser; Toomer, B. Cicely; Steinberg, J. Steven; Moser, W. Hugo; Karaman, W. Mazen; Ramaswamy, Krishna; Siegmund, D. Kimberly; Lee, D. Rick; Ely, J. John; Ryder, A. Oliver; Hacia, G. Joseph (2010). Identification of differences in human and great ape phytanic acid metabolism that could influence gene expression profiles and physiological functions. BMC Physiology, 10(19), 1-10.

Wildman, E. Derek; Uddin, Monica; Liu, Gouzhen; Grossman, I. Lawrance; Goodman, Morris (2003). Implications Of Natural Selection In Shaping 99.4\% Nonsynonymous DNA Identity Between Humans And Chimpanzees: Enlarging Genus Homo. Proceedings of the National Academy of Sciences, 100, 7181-7188. 


\section{The Infeasibility of Cross-Breeding Humans with Anthropoid Apes}

\section{Tonći Kokic**}

\section{Summary}

On the basis of the perspectives of the philosophy of biology and the philosophy of anthropology, this paper claims that, in principle, hybrid offspring between anatomically modern humans and their closest genetic relatives from the anthropoid monkey species is not feasible. However, possible anthropological, moral and ideological implications and arguments linked to the (in)feasibility and attempts at hybridization are not the focus of this paper. The successful hybridization of two different species assumes their genetic and morphological likeness, i.e. a close genealogical relationship. The author believes that there exist genetic and morphological facts that point to the general infeasibility of such hybridization as follows: 1) contemporary scientific knowledge claims a smaller genomic similarity between the two species than was previously thought, and the position of genetic reductionism is weakened; and 2) the morphology of the two species is only apparently similar as they are actually substantively different. A hybrid between these two species is neither logically nor ontologically possible, because it would have to combine the contradictory morphological characteristics of man and animal, namely, specialized animal and non-specialized human characteristics. The human species is also, among its other traits, biologically unique.

Key words: philosophical anthropology, philosophy of biology, genetic reductionism, hybrid, morphology

* Tonći Kokić, Ph.D., Associate Professor, Faculty of Humanities and Social Sciences, University of Split. Address: Poljička cesta 35, Split, Croatia. E-mail: tkokic@ffst.hr 